\title{
The Acts of Lalibäla: a Collection of Fables or an Underestimated Historical Source?
}

\author{
Serge A. Frantsouzoff \\ Institute of Oriental Manuscripts, Higher School of Economics \\ (St. Petersburg), St. Petersburg State University \\ serge.frantsouzoff@yahoo.fr
}

\begin{abstract}
The deeds and exploits of St. Lalibäla who was the most famous king of the Ethiopian Zagwe dynasty are still awaiting to be published in full. To the modern researchers this important medieval text is available only in excerpts published by J. Perruchon in the 19th century. The author argues that Lalibäla's Deeds is far from being an Ethiopian folklore. They comprise valuable authentic data, e.g. the persecution of Lalibäla at the royal court, his escape into the desert, his marriage, his subsequent becoming a king, the organization of his army, taxation policies and history of construction of the famous monolithic churches in the centre of Lasta. The author also argues that the title wäldä nägaśi, which is mentioned in his Deeds as well as its parallel wld/ngšy-n found in Middle Sabaean inscriptions is a sufficient evidence in favour of the military and political continuity between the Aksumite and Zagwe epochs. The Lalibäla's Deeds comprise many minute details about the everyday life, which suggests that the Christians of Ethiopia had a centuries long oral tradition of preserving and transmitting historical information.
\end{abstract}

\section{Keywords}

hagiography - Ethiopian; Lalibäla - canonized King; Ethiopia - Kings; Ethiopia dynasties - Zagwe; Lalibäla his Deeds - authenticity of

The specialists in Ethiopian History had a different attitude towards the historical data as found in various hagiographical texts. Some of them trusted this information completely, whereas others had serious doubts whether they were 
authentic at all. Regardless of this skeptical attitude the Russian Professor Boris A. Turaev, one of the first European specialists on Ethiopian studies, always held high hopes to discover and introduce new sources on Ethiopian hagiography, which would comprise reliable data. ${ }^{1}$ However, in the more recent past the general attitude towards this kind of texts became less optimistic. An Italian Pietroluigi Piovanelli, for example, argued whether it was at all possible to rely upon the data as preserved in the Ethiopian hagiography for reconstruction of the history of the Aksumite kingdom. ${ }^{2}$ In the special volume of the Annales d'Éthiopie, which predominantly deals with the Dossier of Lalibäla, the works on hagiography (including the Lalibäla 's Deeds and other texts of this kind) were very sporadically referred to due to the fact that according to the researchers' opinion they either comprise "very little of the authentic information" or generally suffer from a "general vagueness". ${ }^{3}$

One has to say that after having examined the publication of Lalibäla's Deeds by Perruchon in $1892^{4}$ Boris Turaev was deeply disappointed because the actual contents of the text did not meet his expectations. It was full of endless rhetorical figures, quotations from the Scriptures as well as frequent appeals to its medieval audience. According to Turaev the actual contents of the text could be reduced to one idea, namely that "the Kingdom was bestowed on Lalibäla not to glorify him in this world, but for the churches for him to be erected without wood and clay". 5

A detailed and commented reading of this text with a group of Russian students who specialize in Ethiopian studies has led the author of the present lines to quite a different conclusion. With regard to the 1892 publication one has to say that it seems that Jules Perruchon who was very passionate about the Ethiopian studies selected from the manuscript Or. 718 from the British Museum only those fragments, which appeared to be of the significance to

$1 C f$. his Habilitation thesis published as a monograph: Б. Тураев, Исследования в области агиологических источников истории Эфиопии [Studies in the field of hagiological sources of the history of Ethiopia], St. Petersburg, 1902.

2 P. Piovanelli, "Reconstructing the social and cultural history of the Aksumite kingdom: some methodological reflections," in: Interactions between Rome and the Peoples on the Arabian and Egyptian Frontiers in Late Antiquity, ed. J.H.F. Dijkstra, Gr. Fischer (Late Antique History and Religion, 8), Leuven, 2014, pp. 329-350.

3 M.-L. Derat, "The Zāgwē dynasty (11th-13th centuries) and King Yemrehanna Krestos," Annales d'Éthiopie, 25 (2010), pp. 174-175, 182, 184, 186-187, 188, 189 (pp. 157-196).

4 J. Perruchon (ed.), Vie de Lalibala, roi d'Éthiopie. Texte éthiopien publié d'après un manuscrit du Musée Britannique et traduction française... (Publications de l'École des Lettres d'Alger. Bulletin de correspondance africaine, 10), Paris, 1892.

5 Тураев, Исследования, р. 69 . 
himself. ${ }^{6}$ Among them there is an information regarding the conflict between Lalibäla and the ruling monarch, which was followed by his retirement into the desert, his subsequent marriage, his becoming a King and various military campaigns and taxation of the subjects. The last but nevertheless very significant detail, which attracted the Perruchon's interest was the report about financial aspects regarding the construction of the famous monolithic churches. ${ }^{7}$

The life of the young man who went down in history under the nickname Lalibäla at the royal court was full of dangers. He could not even trust his halfsister who made a clear attempt to poison him. This most likely did happen because she was intending to eliminate one of the probable pretenders to the Ethiopian throne. Luckily Lalibäla had a servant boy in the rank of deacon, ${ }^{8}$ whose duty was to taste his master's food and drink. He drank from the goblet with poison and died on the spot as well as a dog that licked his vomit. After having mourned his servant and the dog (who received identical honours), the future King made up his mind to share their fate and finished the drink. However, but by the Divine providence he did survive and became privy of the mysteries of Heaven and Earth. ${ }^{9}$

Being persecuted by his brother, the then King, Lalibäla ran away into the desert. Contrary to the Saints he did not survive on grasshoppers and honey but fed himself by hunting animals. ${ }^{10}$ One can see that the future King was considered to live as an exile rather than a hermit. ${ }^{11}$ His noble origin, especially his rights to the Ethiopian throne were noticed by members of a rich family who lived locally. They decided to marry him to their daughter Mäsqäl

$6 \quad$ We still do not know why Perruchon did not publish the complete text of Lalibäla's Deeds. Possibly the reason may be quite trivial: for this publication the periodical (i.e. the Bulletin de correspondance africaine) did allocate a limited number of pages because the history of Ethiopia was not among its priorities.

7 One has to stress that no information of this kind could be found in other fragments of the same hagiographic work as well as the so-called Acts of Mäsqäl Kəbra, Lalibäla's wife ( $c f$. St. Kur, "Édition d'un manuscrit éthiopien de la Bibliothèque Vaticane : Cerulli 178," Atti della Accademia nazionale dei Lincei, anno CCCLXIX, Classe di Scienze morali, storiche e filologiche, Memorie, serie viII, vol. XVI, fasc. 7 (1972), pp. 383-426).

8 It is well-known that according to the custom of the Ethiopian Church only minors are ordained to deacons.

9 Perruchon (ed.), Vie de Lalibala, pp. 16-19 (text), 82-85 (French translation).

$10 \quad$ Perruchon (ed.), Vie de Lalibala, pp. 27, 93.

11 An obvious parallel with the youth of the king Sisinnius (Susənyos). In the late 16th early 17 th century $\mathrm{AD}$, before his ascension to the throne, he was also wandering throughout the country and even robbed the people. Later on, he was supported by the nomadic tribes of Oromo, into which he married (С.Б. Чернецов, Эфиопская феодальная монархия в XVII веке [Ethiopian Feudal Monarchy in the 17th century], Moscow, 1990, pp. 9-10, $14-25)$. 
Kəbra. One does not need to say here that according to the Lalibäla's Deeds he met his bride through the Divine arrangements accomplished by an Angel. ${ }^{12}$ While the newlyweds stayed in the house of the girl's father, the "plasterers,

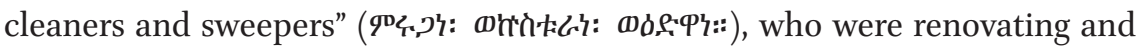
refurbishing their abode, ${ }^{13}$ at the instigation of the devil had spread rumours, which reached the King's ears. According to them the bride of Lalibäla had been already betrothed. ${ }^{14}$ This slander, remarkably was not disputed in the text of the Deeds. The details of Lalibäla's biography as above better fit a vita of a political leader, an adventurer, rather than that of a Saint.

The detailed description of Lalibäla's enthronement lists various stages of

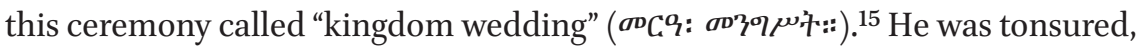
elevated to the throne, ${ }^{16}$ received the new Royal Name, ${ }^{17}$ however, he was strictly speaking not crowned. To stress, no mention of crown at all can be found in the text with regard to this occasion. ${ }^{18}$

An example of the continuity in political terminology between the Aksumite and Zagwe kingdoms was unexpectedly found there. It occurred in the use of the expression wäldä nägaśi, i.e. "the king's son", which can be found in Lalibäla's miracle of his campaign against a rebel. ${ }^{19}$ The commander of the royal army was called twice in such a way, ${ }^{20}$ however, no particular name of his was mentioned there. This does not meet a researcher's expectations, especially if Lalibäla's real son would be meant in that context. The riddle becames

12 Perruchon (ed.), Vie de Lalibala, pp. 27-31, 94-97.

13 Perruchon (ed.), Vie de Lalibala, p. 31.12-13 (the French translation of this passage (p. 97.1819) is inaccurate).

14 Perruchon (ed.), Vie de Lalibala, pp. 31.15-22, 97-98.

15 Perruchon (ed.), Vie de Lalibala, p. 43.22.

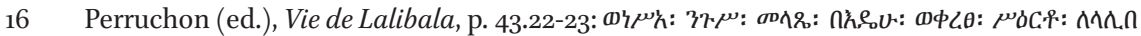

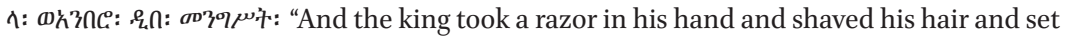
him on the throne".

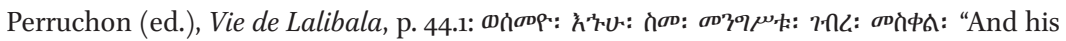
brother (i.e. the previous king - S.F.) gave him the name of his royalty Gäbrä Mäsqäl".

Nevertheless, in the French translation this ceremony is inaccurately called applied to as "la cérémonie du couronnement" (Perruchon (ed.), Vie de Lalibala, p. 109.27). One has to stress here that for the monarchs of the Solomonic dynasty the crown was an inherent symbol of the Royal power. Even imposters did not neglect it, among them the rebel Mälkə'a Krəstos, who pretended to be an uterine brother of the king Sisinnius and in the

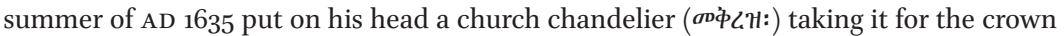
(R. Basset, “Études sur l'histoire d'Éthiopie. $1^{\text {ère }}$ partie," Journal Asiatique, $7{ }^{\text {ème }}$ série, t. XVII (1881), p. 343.26-28). The detailed interpretation of the term mäqräz is given in: С.Б. Чернецов, Эфиопская феодальная монархия, р. 295, n. 4. Perruchon (ed.), Vie de Lalibala, pp. 51-53, 117-119. In the French translation one reads "son fils" or "fils de Lalibala" (Perruchon (ed.), Vie de Lalibala, p. 117.11, 27).

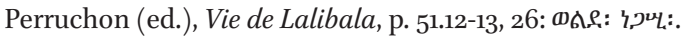


solved when one looks at the Sabaic inscriptions from the 1st half of the $3^{\text {rd }}$ century AD. In this inscription the combination of words as wld ngšy-n (presumably a title) was applied to the commander of Abyssinian troops in South Arabia. $^{21}$

Another miracle of Lalibäla comprises a valuable information on taxation in early medieval Ethiopia. According to it the taxes were collected as tribute, normally in the form of natural products, such as honey in pots. ${ }^{22}$

The physical construction of the colossal complex of monolithic churches originally known as Roha (Edessa) in the heart of the province of Lasta cannot be explained to be possible in the society predominantly based on the natural economy. However, one can find an explanation in the then history of the Coptic Church. At the end of the time of Crusaders its members were severely persecuted by Muslim authorities, so that didn't possess any means to construct new churches on the territories controlled by Muslims, but still could to invest into the building churches elsewhere. ${ }^{23}$ This suggestion is textually supported by Lalibäla's appeal to the workers who constructed the churches. The King-

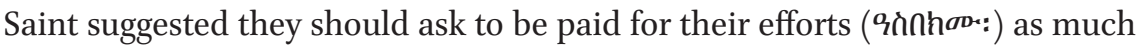
as they would like. And indeed, he was able to pay their wages regularly from the day they began the construction until they completed their work. ${ }^{24}$ An act of obvious generosity could only take place, if the king would have had at his full disposal money provided by very wealthy donors and benefactors.

Numerous details as preserved for us by the Lalibäla's Deeds deal mostly with the everyday life. These are valuable since as a complex they portrait the life of the Zagwe epoch, which still remains the least researched aspect of the Ethiopian history mostly due to the lack of written sources. The question arises about how could be these valuable data incorporated in the hagiographic tale from the 14th-15th century $\mathrm{AD}$ ? The most probable answer is to admit the existence of a parallel orally transmitted historical tradition, which was living for centuries among the Ethiopian Christians.

$21 \quad C f$. Ch.J. Robin, "La première intervention abyssine en Arabie méridionale (de 200 à 270 de l'ère chrétienne environ)," in: Proceedings of the 8th International Conference of Ethiopian Studies (Unversity of Addis Ababa, 1984), ed. Taddese Beyene, vol. 2, Addis Ababa, 1989, pp. 150, 153 .

22 Perruchon (ed.), Vie de Lalibala, pp. 46-49, 112-115.

23 С.А. Французов, “Лалибэла” [Lalibäla], in: Православная энциклопедия [The Orthodox Encyclopaedia], t. XxxIx, Moscow, 2015, p. 718.

24 Perruchon (ed.), Vie de Lalibala, pp. 56-57, 122-123. 